\title{
The political economy of Kulturkampf: evidence from imperial Prussia and republican Turkey
}

\author{
Ioannis N. Grigoriadis ${ }^{1}$ - Theocharis N. Grigoriadis ${ }^{2}$ TD
}

Published online: 22 March 2018

(C) Springer Science+Business Media, LLC, part of Springer Nature 2018

\begin{abstract}
This paper analyzes the political incentives of Kulturkampf and the implementation of secularization in imperial Prussia and republican Turkey. A game-theoretic model defining Kulturkampf as a static game between priests and the executive is proposed. The willingness of priests to accept the government's offer and be transformed into bureaucratic experts varies. Individualist priests are easier to recruit as they care more about their personal welfare than social distribution by the church, whereas the reverse holds for collectivist priests. Nevertheless, the longrun success of the Kulturkampf depends on the effective recruitment of collectivist priests and their entry into formal politics in favor of the executive.
\end{abstract}

Keywords Kulturkampf $\cdot$ Prussia $\cdot$ Turkey $\cdot$ Secularism $\cdot$ Protestantism $\cdot$ Catholicism · Islam $\cdot$ Enforcement $\cdot$ Bureaucracy $\cdot$ Expertise

JEL Classification $\mathrm{P} 16 \cdot \mathrm{P} 51 \cdot \mathrm{Z} 12$

The authors are grateful to the Editor, Stefan Voigt, and two anonymous reviewers for useful comments and suggestions. All remaining errors are ours.

Theocharis N. Grigoriadis

theocharis.grigoriadis@fu-berlin.de

Ioannis N. Grigoriadis

ioannis@bilkent.edu.tr

1 Department of Political Science and Public Administration, Bilkent University, 06800 Ankara, Turkey

2 School of Business and Economics, Institute of East European Studies, Free University of Berlin, Garystr. 55, 14195 Berlin, Germany 


\section{Introduction}

The role of religion has remained a key question in all political modernization projects. A pool of crucial symbolic resources, religion has been instrumentalized, co-opted or repressed, depending on the ideological identity of regimes. ${ }^{1}$ The historical development of Calvinism as a reaction of Northern European principalities to the Vatican's political authority treats religion as a rationalization movement against administrative centralization and social arbitrariness. ${ }^{2}$ Iannacone et al. identify the location of sacred spaces as a game-theoretic problem between secular and religious powers. Market coordination, free competition and the neutral nexus are equilibrium solutions analyzing the church-state interaction in Western Europe, the United States, as well as in ancient Greece and early Israel (Iannaccone et al. 2011, 327-330). In the cases of Ottoman and republican Turkish modernization, religion has been treated either as a crucial instrument that would render modernization compatible with local and national values or as a parochial vestige to be defeated and removed from the public sphere. Resistance against centralization and arbitrary rule was often expressed in religious terms, and this reinforced the significance of religion as an object of political and social debate and confrontation.

Greif's theory of collectivist and individualist economies (1994) originates from the observation that enforcement rules, intereconomy relations, commercial networks structure and wealth distribution were diametrically different in Genoese and Maghreb merchants. These differences are attributed by Greif to cultural beliefs, which lead to collectivist and individualist economic systems; collectivist economies are more protectionist and require cheaper formal institutions for law enforcement, while individualist economies advance intereconomy relations and thus require higher enforcement costs.

The symmetric analogy, according to Greif, between individualist economic systems and developed economies, on the one hand, and collectivist economic systems and developing economies, on the other, indicates that cultural values can be significant for economic development, state organization and capacity. Moreover, cultural values seem to matter not only because they are reflected in contract enforcement and market development, but also because they necessitate different administrative mechanisms and rules for their perpetuation.

Individual ideas can be transformed to collective values through religion. Weber's Protestant Ethic and the Spirit of Capitalism provides a developmental history of Western capitalism derived from the economic ethics of Reformation and

\footnotetext{
1 Religion has been historically instrumental in state formation and administrative enforcement. States use religious legitimacy to enforce their administrative authority or proclaim their separation from religion in order to facilitate equality among their citizens. The influence of religious norms on states, administrations and citizens is not a matter of rhetorical adherence but institutional continuity. In the nineteenth century, Catholicism was perceived as an obstacle to progress and state-building in diverse European contexts (Werner and Harvard 2013, 13-24).

2 As Gorski (2003: 31-34) suggests, Calvinism created the conditions for disciplinary revolutions in the Netherlands and Brandenburg-Prussia; in this sense he uses the term disciplinary revolution as a substitute to Marx's bourgeois revolution.
} 
its asceticism, as this is reflected in the private sector of nineteenth century Germany, Western Europe and the United States. ${ }^{3}$ Furthermore, Weber (1920) has been a pioneer in the analysis of religions as economic systems and therefore has identified Protestantism, Catholicism and other world dogmatic traditions as conducive to ideal forms of socio-economic organization. In the Weberian worldview, religions are instrumental institutions that facilitate the realization of public policy objectives. Ostrom (2000) underscores the significance of social norms that underpin shared beliefs on resource distribution and therefore sets the foundations for the introduction of Greif's initial typology into the context of religion. The distinction between collectivism and individualism does not capture only differential responses to commercial ethics violations, but also differential commitments to social welfare and the church as an institution. La Porta et al. (1997) indicate that vertically organized religions such as Catholicism, Orthodoxy and Islam are more prone to underdevelopment, while Geissbuehler (2007) observes a higher propensity of Catholicism in Switzerland toward political mobilization for social welfare, lower identification levels with the Nazi party, family and community values and an overall anti-capitalist stance.

The theory of club goods (see, e.g., Gilles and Scotchmer 1997) is extremely useful for understanding the relation between religious identity and local public goods. It allows decentralization to be linked to the efficient delivery of common pool resources by any religious collective. ${ }^{4}$ If the religious collective is treated as a club and the goods that it offers to its members as club goods, then administrations can also be modeled as quasi-clubs that derive authority from the religious tradition shared by the majority. For example, Berman (2000) argues that the structure of the ultra-Orthodox yeshiva (Orthodox Jewish school or seminary) is very explicit about the use of observance and dietary prohibitions on the haredim (ultra-Orthodox Jews) as extreme-form taxes on secular activity outside the collective. Accordingly, the opportunity cost of secular life decreases, and members of ultra-Orthodox communities socialize with other members and produce positive externalities for their collectives, such as higher fertility rates.

It is important to keep in mind that there are multiple ways in which religion matters for the support of political preferences. Political culture is usually defined as a set of values that reveal the preferences of the majority on dichotomous issues such as social welfare versus equality of opportunity (Feldman and Zaller 1992). Thus, religion can be used in politics as an agenda-setting factor with respect to issues of minority rights protection. It is, in addition, a model of administrative organization, is useful for community development and is an institutional parameter for welfare provision arrangements.

\footnotetext{
3 Schluchter Wolfgang, Rationalism, Religion and Domination, University of California Press, Berkeley and Los Angeles, 1985: 27-29.

4 They suggest that the provision of local public goods is efficient under the condition that citizens preserve the opportunity to conclude labor contracts in neighboring localities. This is certainly the case for Israeli kibbutzim but not for Eastern Orthodox monasteries and Muslim tariqas.
} 
In modeling secularization as a game of civil service and bureaucratic expertise, we were mainly influenced by (Gailmard and Patty 2007). For a broader overview of the key literature on bureucratic discretion, agency and informativeness, it is important also to consider (Gailmard 2009) and (Epstein and O'Halloran, 1994). While both finding a new role for religion in the public sphere and regulating its relations with the state have been a concern of all modernizing states, the level of confrontation inherent to this transformation has been higher in some cases. Imperial Prussia and republican Turkey were two states in which this process took the dimensions of a "culture war," a Kulturkampf. While the very German origin of the term Kulturkampf points to the relevance of the Prussian experience, in the case of Turkey the idiosyncrasies of Turkish modernization have raised the relationship between religion and politics to one of the defining features of republican Turkish politics. This study compares the political incentives of Kulturkampf and the implementation of secularization in imperial Prussia and republican Turkey. Both cases reveal the limits of secularization as a set of enforced state policies aiming to achieve:

(a) full state control over religious institutions;

(b) transformation of religious personnel into bureaucratic experts; and

(c) the official status of a religious group over minorities that are in much higher need of preserving their public and social position.

We propose and solve a game-theoretic model transcending the domains of Christianity and Islam. The state transforms religious personnel into bureaucratic experts through material persuasion and repression. In a two-period game, optimal levels of wages and repression technologies depend on the wage offered to priests by their church and the initial degree of social distribution. It is harder to secularize and politicize collectivist priests than individualist priests because repression technology is always costlier for the government than the provision of material benefits. Failures of the Kulturkampf in Germany and Turkey argue for the non-sustainability of repression technology as a recruitment mechanism for collectivist priests over a long-term time horizon. What we show is that the entry of collectivist priests into formal politics in favor of the executive consolidates the long-run success of the Kulturkampf. Upon recruitment by the government, collectivist priests would require a higher material reward in order to enter politics in support of the religious policies of the state, which reveals the core challenge for Kulturkampf success. This model advances the work of Iannaccone et al. (2011) in the game-theoretic analysis of religion-state relations by focusing on state policies of secularization (Iannaccone et al. 2011; Iannaccone et al. 2011; Iannaccone et al. 2011). While the authors are aware of the limits that different historical and cultural contexts put on such a comparative analysis, this strong legacy renders the comparison of the two countries possible, as well as meaningful and interesting. It sets a blueprint for the comparative study of modernization in diverse historical contexts.

This paper is structured as follows. In Sect. 2, we offer a comparative-historical analysis of the Kulturkampf in Germany and Turkey. In Sect. 3, we contextualize 
our game-theoretic model by providing an overview of collectivism, individualism and the limits of the Kulturkampf. Section 4 focuses on a game-theoretic model of secularization and bureaucratic expertise with reference to individualist and collectivist priests. Section 5 discusses the challenge of multiculturalism and integration in Germany, Europe and beyond. Section 6 concludes.

\section{Varieties of Kulturkampf: imperial Prussia versus republican Turkey}

The German lands were among the most affected by this divergent relationship between the state and the church in Western and Central Europe. As the German Empire which emerged following the Franco-Prussian War of 1870-1871 consisted of Protestant and Catholic populations and included Catholic_-mainly Polish—ethnic minorities, it needed to address this religious and cultural bifurcation during its state-building process. One of the key reasons for the ensuing Kulturkampf (Ross 1998a) was the decision of the German Chancellor Otto v. Bismarck to build German national identity on Protestant cultural foundations, increase state authority and control over religious institutions and sever the links between Prussian Catholics and the Vatican.

While historically conditioned by German unification and the emergence of Prussia as its driving force, the notion of Kulturkampf has been observed in a wide range of historical and institutional contexts unrelated to its Protestant origins. Russian expansion to Central Asia in the second half of the nineteenth century resulted in a system of religious education composed of parochial and collegiate schools (Zenkovsky $1955,19-22,26-30)$. The creation of a competing schooling system that would transmit Western cultural values and adjust local populations to the more Europeanstyle culture of Russia can provide a basis for understanding Kulturkampf dynamics through the channel of religious versus secular education rather than that of the clergy's state incorporation (Zenkovsky 1955, 24-26). Similarly, the distinction between Israel's secular and religious cultures in its public sphere has led to inconclusive culture wars in that country (Katz 2008). These are reflected in the Israeli political party system and also frequently refer to disputes regarding observation of the Sabbath holiday in the public sphere. Hence, the multiplicity of definitions of the Kulturkampf suggests that state intervention in religious affairs has the propensity to trigger interdenominational conflicts beyond the framework of clerical cooptation and certainly under variable socio-economic and political conditions.

In Turkey, Kulturkampf has been observed in different phases of the Republican modernization program. In the late 1920s and early 1930s it was framed around Ataturk's Westernization radical secularization program. Since the advent of multi-party politics and the rise of Turkish political Islam, Kulturkampf has been revamped as a fight for Turkish public sphere between secularists and Sunni conservatives. The rise of political Islam to a hegemonic position has moved the Kulturkampf debates to the ongoing Islamization of Turkish state and the public sphere. The attempt of Republican Turkish state to control Sunni Islam and its institutional manifestations, on the one hand, and the confrontations between political and social groups which saw in Sunni Islam a scapegoat for all the Turkish ills or a panacea 
which would heal all political and social problems, on the other, have preserved the long-run relevance of Kulturkampf. State attempts to instrumentalize religion and that way exercise strict control over the society have been ceaseless despite being met with limited success.

\subsection{Imperial Prussia}

The Kulturkampf in imperial Prussia between 1871 and 1878 indicated the resolve of Chancellor Otto von Bismarck to consolidate the institutional position of the Lutheran Church as an arm of the Prussian state and eradicate the influence of a transnational religious authority, the Vatican, in the administrative affairs of imperial Prussia. Anderson argues that the focus of the Kulturkampf did not lie on the reduction of episcopal influence on Prussian politics per se, but in the polycentric organization of the Catholic political milieu in the aftermath of Bismarck's antiCatholic laws (Wiermann 1885, 102-103, Anderson 1986). Bishops were no longer the sole source of Catholic authority: Anderson's hypothesis is that the rise of the Center Party under the leadership of Ludwig Windthorst and its network, the lower clergy, the press and the Volksverein were indicators for the democratization and laicization of German Catholicism as a result of Kulturkampf policies (Wiermann $1885,102-103)$. Secularization did not mean the removal of religion from the public sphere, but the empowerment of parish clergy vis-à-vis its own bishops. Johann Alois Dauzenberg, a priest who had been discharged as school inspector because he ran as a Center Party candidate, strongly reacted against the bureaucratization of religious instruction (Lamberti 1989, 58); nevertheless, the political agenda of the Center Party continued to be defined by laymen (Wiermann 1885, 102-103). This identity formation process took place at the expense of the higher ranks of the Catholic Church in Prussia, but, at the same time, it transformed the lower clergy into the key church stakeholders of the Catholic question in Prussia. ${ }^{5}$ The fortunes of political Catholicism as represented by the Catholic Center rose together with the repressive measures of the Prussian state (Altınordu 2010, 534-536).

School supervision and a series of extensive reforms of the school curriculum became also the core of Bismarck's Kulturkampf agenda; the School Supervision Law of March 11, 1872, defined school inspection as a state office and targeted severely schools in the Rhine Province and the Posen region (Lamberti 1989, 43-47). While in Protestant schools the subject of religion was taught exclusively by professional educators, in Catholic schools it was divided between lay teachers and parish priests; nevertheless, the mobilization of the Catholic clergy against

\footnotetext{
5 A similar trend could be witnessed within the non-Muslim communities of the Ottoman Empire, where Tanzimat measures in the mid and late nineteenth century contributed to the rise of secular interest groups and the challenge of the hegemonic position of religious institutions (Issawi 1982; Davison 1982). The term Tanzimat (meaning reform in Ottoman Turkish) refers to a historical period and a political movement that dominated Ottoman politics between 1839 and 1876. The Ottoman Empire was then ruled by Sultans and bureaucrats who realized that the reversal of the decline or even the very survival of the Ottoman Empire was contingent upon the implementation of an ambitious and courageous program of Westernization reforms.
} 
Adalbert Falk's law was restrained by the discretionary power of local inspection officers to ban priests from teaching in case of the latter's' anti-government political involvement (ibid., 55-59). It is important to keep in mind that political Catholicism already before the German unification had organized itself into a party fraction in the Prussian House of Deputies, whose goal was to defend the Catholic political agenda (Nipperdey 1990, 732-735). As Nipperdey (1998, 372-382) points out in his own account, a combination of domestic and foreign policy considerations bolstered the outbreak of the Kulturkampf in Prussia shortly after the formation of the German Empire; the Polish and Old Catholic questions, the possible emergence of an antiGerman Catholic alliance in Europe and Bismarck's resoluteness against an influential political Center rendered violent secularization into the core of Prussian public policy and a long-run failure both for the government and liberals.

\subsubsection{State control of religion}

Some of the measures that the Prussian government took in this respect included the abolition of the Catholic section in its Kultusministerium in 1871, the elimination of Catholic influence over school curricula, the exclusion of religious orders from school teaching and the expulsion of the Jesuit order from Germany in 1872 (Ross 1998b, 6). The reaction of the Vatican and Pope Pius IX himself against these measures did not prevent the inauguration of a conference on the regulation of state-church relations in the Prussian Kultusministerium on 3 and 4 August 1872 (Lange 1974, 22-23). The so-called May Laws were derived from this conference and entered into force almost a year later, in May 1873. The May Laws introduced the following changes: (a) Religious duties could be performed only by clergymen that had completed a three-year university course and passed a Kulturexamen (11 May 1873); (b) A newly established royal court of ecclesiastical affairs assumed all disciplinary competencies over German priests; the state, rather than ecclesiastical courts, was entitled to decide on the validity of disciplinary measures imposed by ecclesiastical authorities (12 May 1873); (c) The effects of ecclesiastical disciplinary measures were constrained to the purely religious sphere (13 May 1873); and (d) The civil effects of ecclesiastical withdrawal were regulated in the same direction (14 May 1873) (Lange 1974, 23-24).

To expedite the effects of the May Laws on the status of the Catholic Church in imperial Prussia, in 1874 the government initiated some additional laws that specified or expanded the regulatory reach of its previous initiatives as follows:

(a) Civil marriage became obligatory as of 9 March 1874;

(b) Clergy that did not meet the appointment requirements of the First May Law were sent to another area and in the case of reoffending they were stripped of their citizenship and expelled from the territory of the German Empire;

(c) In cases where episcopal regents were not elected in accordance with the provisions of the May Laws, a state commissioner would assume authority over the property of the diocese; and 
(d) In cases of accusations of office usurpation, the clergymen concerned had the burden of proof of their honesty and it was in the court's discretion to seize the respective office property (Lange 1974, 24-25).

Obligatory civil marriage was extended to all German states in 1875; all Catholic orders were dissolved, while church councils and community representatives were forced by the state to improve the monitoring of church property. By 1876, all of the property of the Catholic Church in imperial Prussia had come under governmental custody (Lange 1974, 25-26).

\subsubsection{Bureaucratization of religious personnel}

The formation of the German Empire gave rise to the first modern welfare state and facilitated the reinforcement of a middle class earning money from agricultural business, industrial innovation and the development of small and medium enterprises. The Catholic Church was seen as a continuous impediment to German unification and the hegemonic role of imperial Prussia as a Lutheran state in both Germany and Europe. The Prussian Kulturkampf between 1871 and 1878 can be explained by the following sets of incentives:

(a) Bureaucratic expansion and improvement of hierarchical monitoring;

(b) Provision of public goods and social services through government channels;

(c) Treatment of the state as the sole institution that can represent and optimize collective interests; and

(d) Transformation of clergymen into bureaucratic experts.

Policies such as state supervision of religious appointments, university training of the clergy and public management of ecclesiastical property increased state revenues and incorporated the Catholic Church into the imperial administrative system. This abrogation of ecclesiastical autonomy and subjugation of church resources to state control are in line with the basic organizational premise of Protestantism arising from the Augsburg Peace Treaty in 1555 (cuius regio eius religio). Furthermore, the identification of all spiritual activities with the Prussian state undermined religious institutions as competitive or complementary welfare providers.

Until the Kulturkampf, the performance of religious duties by the Catholic clergy was monitored by the spiritual authority of the Vatican and the local government. The substitution of this dual accountability mechanism with a single monitoring institution transformed the Catholic clergy from religious minority representatives to bureaucratic experts who could pursue their spiritual agenda only in accordance with public finances and the policy preferences of the Prussian bureaucracy. It is important to point out that the church tax was levied through the state, which indicates how dependent the Catholic clergy was on the public finances and policy preferences of the Prussian government. The transformation of religious officials into bureaucratic experts implies that the commitment to collective welfare becomes 
an issue of result-driven administrations rather than hierarchy- or network-driven institutions.

\subsubsection{The rise of Protestantism to official status}

The traditional dichotomy between ultramontanism and liberalism reflected broader ideological divisions in German society. ${ }^{6}$ The fierce anticlericalism of German liberals was combined with Bismarck's motivation to render the main parliamentary group that represented Catholic interests in the parliament, i.e. the Center fraction, politically irrelevant. In this sense, the initiation and entry into force of Kulturkampf laws between 1873 and 1875 and the administrative enforcement of criminal punishments by the bureaucracy mirrored the coalition between the liberal majority in the parliament and the executive branch of the Prussian government (Uwe 2010, 194-195). The metaphysical dimension of the conflict became very acute, as the status of the Catholic Church in society was transformed from a sacred institution whose sovereignty was based on divine law to a secular institution whose legitimacy was founded on public law. Prussian criminal courts dealt with many cases of clerical disobedience against the May Laws and their subsequent derivatives, a reality indicating that the secularization was the outcome of unilateral state violence rather than a concordat. This use of criminal law and procedure undermined the authority of criminal courts, but it also established a negative precedent about the independence of criminal justice, which was to be used by extremist political groups in the years to come (Uwe 2010, 194-195).

While disciplinary measures against the Catholic Church heavily influenced its social status and the quality of its financial and human resources, the Prussian authorities did not manage to eliminate the Catholic Center from Prussia's representative institutions. This reality motivated Bismarck to advance a conservativecentrist parliamentary coalition at the federal level when the national liberals refused to support his trade protectionism policy and the imposition of import tariffs. The magnitude of this change became obvious with the dismissal of the Minister of Culture Adalbert Falk and his replacement with Robert v. Puttkamer (Morsey 2000, 23). Contrary to Falk, who was a hardliner and instrumental in the passing of Kulturkampf laws, v. Puttkamer was more moderate and sought channels of communication with the Catholic Church. While political necessity required a rapprochement between Berlin and Rome, Catholicism as a political lobby never again attained the level of institutional and economic independence it had enjoyed in Prussia before 1871.

The political and economic logic of Bismarck is crucial here if we are to model Kulturkampf as a violent transition from dualism to secularization. In his parliamentary speech of 10 March 1873, he argued that the Kulturkampf was not a unilateral struggle of a Protestant dynasty, the Hohenzollern, against the Catholic Church or

\footnotetext{
${ }^{6}$ On this, also see the paradigmatic case of the Moabiter Klostersturm (Borutta 2003, 228-237), when rising anti-Catholicism in Berlin led a mob to violently protest against a Catholic monastery in Moabit (1869).
} 
a war between faith and absence of faith. On the contrary, the Kulturkampf wasaccording to Bismarck-yet one more manifestation of the traditional struggle between the church and the state. He understood the transformation of Catholic priests into Prussian bureaucratic experts as a sine qua non modernization condition, which may guarantee internal stability and recognition of the Kaiser's sovereignty as both Prussian king and German emperor. In his speech of 24 April 1873, he suggested that the Catholic Center had no right to speak in the parliament as the representative of the Catholic Church (Böhm 1891, 228-229). ${ }^{7}$ The dissolution of precisely this principal-agent relationship was one of the key Kulturkampf objectives, and it is obvious that it largely succeeded in this respect. The Catholic Center failed to prevent the May Laws and other law bills from entering into force and being implemented in the territory of Prussia, and, as a result, it was never again able to actively support a continuation of the Vatican's formal interference in Prussia's ecclesiastical affairs. It must be stressed here that Bismarck did not stage the Kulturkampf in order to aggrandize the Evangelical Church in imperial Prussia. His rejection of the church as a community that could determine state interests constituted the core of his general predisposition toward all types of religious institutions (Kars 1934, 60-63).

The identification of political Catholicism with the German Mittelstand and the inclusion of the interests of peasants, craftsmen and small entrepreneurs in the electoral process pose an alternative thesis to Sperber's treatment of Catholic political mobilization as synonymous to anti-liberal and anti-industrial policies (Sperber 1983; Evans 1984). Anderson and Barkin propose that the implementation of $\mathrm{Kul}$ turkampf policies under the ministry of Puttkamer in 1878-1879 must not be seen solely as a full-scale attack against liberal ideas (Anderson and Barkin 1982). They argue that the Kulturkampf brought about the introduction of the Catholic milieu into mainstream German politics ${ }^{8}$; nevertheless, the Center Party remained throughout the Kulturkampf an opposition party. Its success as a political organization signals the limits of Bismarck's secularization program.

\subsubsection{Persistence of Kulturkampf: the Catholic Church and the Nazi regime}

The resistance of Catholic institutions against National Socialism in Westphalia, Berlin and other regions of Prussia reveals that centralizing administrative policies continued to treat the Catholic Church and its organizations as a source of deviation from a repressive model of church-state relations. Lahrkamp (1986) observes that Catholic youth organizations were the first to be targeted by Nazi authorities already in 1933. Popular support for the bishop of Münster was seen by the regime as a provocation that undermined social coherence; farmers and local leaders were explicitly discouraged by Nazi party members and the police from organizing and participating in public rallies and many of those who did not obey were arrested

\footnotetext{
7 Similar were the attempts of the state religious establishment - the Diyanet-in Turkey to disprove the claims of Turkish political Islam that it was the authentic representative of the Sunni conservative citizen.

8 See also Kars $(1934,60-63)$.
} 
(ibid.: 163-164). Contrary to the Prussian government during Kultukampf, the Nazi regime did not attack or arrest bishops; on the contrary, it focused rather on parishioners and low-ranking members of religious orders (ibid.).

Hence, the anti-Christian character of Nazism and its profound animosity against the cosmopolitan and transnational orientation of the Catholic Church set the foundations for a politicized and at the same time antagonistic relationship (Spicer 2004; Evans 2007). As evidence from Berlin in the 1930s indicates, the persecution focus of the Gestapo was on active priests rather than outspoken bishops (Spicer 2004). This difference between the Bismarckian Kulturkampf and the anti-Catholic stance of the Nazi regime suggests that mass indoctrination rather than elite formation was a major priority for National Socialists. While the resistance of the Catholic clergy was neither uniform nor widespread across and within ranks (Spicer uses the insightful term Resistenz instead of Widerstand), it provided a solid basis for civil society resilience under the totalitarianism of the Nazi regime.

\subsection{Republican Turkey}

Bismarck's efforts to dominate the Prussian public sphere through the abolition of Catholic institutions and the removal of religious symbols that challenged the official national ideology found resonance in republican Turkey decades after the culmination of the Prussian Kulturkampf. The roots of the Turkish Kulturkampf can be, however, traced in the nineteenth century and the late Ottoman modernization program, known as Tanzimat. These were linked with the reinforcement of state grip on religious affairs, in parallel with imperial German state policies. The 1826 elimination of the Janissary corps with its strong Bektaşi ${ }^{9}$ affiliation was the first step of a long-term campaign to impose state control on diverse unofficial and semi-official Islamic institutions which had supported Ottoman Islamic pluralism and questioned the monopoly of state authority over Islam. Unlike in the case of imperial Prussia, Kulturkampf did not gain momentum in the second half of the nineteenth century. The culmination of this process occurred decades later, when the collapse of the Ottoman Empire and the advent of republican Turkey in 1923 created conditions suitable for the implementation of a radical secularization program. While the number of non-Muslim citizens had sharply fallen following the wars that marked the end of the Ottoman Empire and the emergence of republican Turkey, there remained a considerable degree of diversity within Turkey's Muslim population. Alevis, Shiites, Sufi Islamic brotherhoods and other schools of Sunni Islamic jurisprudence maintained considerable influence alongside official Hanafi Sunni Islam. ${ }^{10}$ The Turkish Kulturkampf was recrystallized in the early years of the Republic as a

\footnotetext{
9 The Bektaşis was a Sunni religious order that grew together with the expansion of the Ottoman Empire in the Balkans in the fourteenth and fifteenth centuries. Due to its syncretistic character and relative toleration of lifestyles and attitudes deviant from the Sunni mainstream, it became very popular among Balkan converts to Islam, including the Janissaries, the Ottoman military corps whose members were traditionally enlisted through a children levy (devssirme) from the non-Muslim populations.

10 On the rise of Sufism in the Islamic world, see Karamustafa (2007).
} 
struggle between the incumbent Kemalist reformist elite and the peripheral social forces that favored some degree of continuity with the Ottoman state of affairs. In his seminal study on center-periphery relations in Turkey, Mardin identified the critical role of religion in this context (Mardin 1973, 309-315). Secularization was not expressed in terms of keeping an equal distance from different religious denominations. It was expressed in terms of abolishing the Caliphate, ${ }^{11}$ namely ending the function of religion as source of state legitimacy and removing it from the public sphere while at the same time capitalizing on its integrative potential. Sunni Islam remained the strongest cementing factor of republican Turkey's majority group, which was characterized by a considerable degree of ethnic, linguistic and cultural diversity. On the other hand, it also entailed full state control of religion, bureaucratization of its personnel and the elevation of Sunni Islam into de facto official status while eliminating any non-official, heterodox versions of Sunni Islam (Dressler 2013, 140-149).

\subsubsection{State control of religion}

One of the key features of republican Turkey's policy toward religion was to subordinate it and remove it from the public sphere. The abolition of the Islamic tarikats ${ }^{12}$ and other movements was a key element in the process of complete subordination of Islam to the state and was reminiscent of the German abolition of the Jesuit order. In the mid-1920s, Turkish Islamic functionaries were presented with dilemmas similar to those Catholic priests had encountered about 50 years before. Incentives and repression were variably employed in order to achieve complete state control over religion. Mainstream Sunni Hanafi imams appeared more willing to cooperate with state policies. In addition, full control of religion by the state was not tantamount to an absence of preference between religions.

Like Protestantism in imperial Prussia, Sunni Hanafi Islam enjoyed a de facto official status and legitimacy against peripheral, tarikat-affiliated versions of Sunni Islam as well as peripheral Islamic denominations, in particular Alevism. Following the proclamation of the Republic of Turkey in 1923 and the formal abolition of the Caliphate in 1924, the state pursued the full subordination of official Sunni Islam and the elimination of its tarikats. In 1924, according to the provisions of the Law on the Unification of Education (Tevhid-i Tedrisat), religious schools (medreses) were closed and secular schools (mekteps) were made the sole institutions of education (Baltac1 1993, 14). Religious education was not eliminated, but it came under the supervision of the Ministry of National Education (Kaymakcan 2006, 486). This was analogous to German attempts to impose strict state controls on Catholic

\footnotetext{
11 As republican Turkey, following the cataclysmic changes that sealed the end of the Ottoman Empire, was immersed in nation- and state-building, the loss in international influence that the abolition of the Caliphate meant did not appear to be a significant concern.

12 The term tarikat originates from the Arabic Word tarik, meaning "path", "way" and refers to Sunni religious orders that acquired substantial albeit unofficial influence within the Muslim population of the Ottoman Empire. As they suggested alternative paths towards God that deviated from mainstream Sunni Islam, tarikats usually faced the suspicion, if not the outright animosity of the Ottoman state.
} 
education. The aim of the reform was to prevent the rise of an informal religious education system and establish a state-controlled mainstream view of Sunni Islam (Ayhan 1999, 64). In this context, secularization meant ending the traditional power of the ulema and the tarikat leaders ${ }^{13}$ and promoting the vision of a state-sponsored "rational religion". By "rational religion" one meant "to reduce the social significance of religious values and to eventually disestablish cultural and political institutions stamped by Islam.” (Tank 2005, 6).

\subsubsection{Bureaucratization of religious personnel}

In the case of Sunni Islam, the transformation of religious functionaries into bureaucratic experts required the cooptation of mainstream Sunni Hanafi religious leaders who had been Ottoman state functionaries, as well as the marginalization of tarikats and non-Hanafi Islam and the consolidation of state control over its own religious bureaucrats. The abolition of the Caliphate and the office of sheikhulislam was followed by the establishment of the Presidency of Religious Affairs (Diyanet) in 1924, a bureaucratic authority whose duty was to administer and control Sunni Islam, the mosques, pious foundations and the religious personnel. (Gözaydın 2009). These steps aimed to centralize the administration of Sunni Islam as well as secure the loyalty of religious functionaries to the republican regime and their full support for its reform program (Berkes 1964, 484). The Diyanet integrated all Muslims under a state-controlled Sunni-inclined administration subservient to the state aims of rationalizing society and privatizing religion. Sunni Islamic organizations which were not linked with it were suppressed, while public manifestations of Sunni Islam were curtailed. The Diyanet emerged as the sole and exclusive legitimate Islamic institution in the country, aiming to turn all imams and hatips into bureaucratic experts. The training of religious functionaries became an exclusive competence of the state. This phenomenon is in line with Prussia's May Laws that made university education mandatory for Catholic priests. The Turkish law on unification of education also lay down the foundation of new schools to train religious personnel. Therefore, imamhatip schools (religious vocational high schools) were founded with this name in the year of 1924. Accordingly, imam-hatip schools and a faculty of divinity at Darül-Fünun, later Istanbul University, were established (Berkes 1964, 484). The aim behind the establishment of these institutions was to eliminate the influence of nonstate religious actors in religious education (Unan and Hacaloğlu 1999, 250-251).

\subsubsection{The rise of Sunni Islam to official status}

While in the early republican years the Diyanet served one of the key regime objectives, namely the privatization of religious affairs, it maintained an impeccably Sunni profile against other religions and Islamic denominations, in particular

\footnotetext{
13 Similar to the case of imperial Prussia, the dissolution of this principal-agent relationship was one of the key Kulturkampf objectives which proved successful. Neither Tarikat leaders nor ulema but the rising Islamic bourgeoisie provided leaders for the rising Turkish political Islam from the 1960s onwards.
} 
against Alevi Islam (Dressler 2008, 289-290). State control of Sunni Islam also meant public support for Diyanet-controlled mosques and Sunni religious functionaries, but the ban on all tarikats meant that non-mainstream Sunni, Alevi and other Islamic groups could not maintain a legal existence and had to dissolve or go underground. On the contrary, during the Prussian Kulturkampf there has been a strengthening of Catholic civil society, as this has been manifested with the massive establishment of Catholic Associations (Vereine) and the emergence of the Catholic milieu. The lack of legal status for non-Sunni Islamic denominations also meant that the state would condone a de facto proselytization campaign by lending financial and institutional support for Sunni Islam. This privileged position is reminiscent of that of Protestantism in imperial Prussia. The stakes increased as Sunni Islam was gradually rehabilitated into mainstream politics (Grigoriadis 2008, 98-102). The terms of the Kulturkampf began undergoing a transformation in the late 1960s, following the relative liberalization of Turkish politics and the continuation of state suppression of religion, as non-statecontrolled political Islam rose to political prominence and an Alevi political movement emerged in a pattern reminiscent of the rise of Catholic Center party in imperial Prussia. A struggle between the secularist bureaucratic elite of the country and the rising Muslim bourgeoisie, which had spearheaded the rise of Turkish political Islam since the late 1960s, was the consequence. The emergence of Islamist political parties that challenged the state monopoly of Sunni Islam reflected this struggle, which allowed tarikat representatives to win seats in the Turkish parliament while staying short of acquiring bureaucratic posts. While the struggle between secularists and Sunni conservatives lingered, the recognition of Alevi identity and rights and the end of state assimilationist policies became a second front in the Turkish Kulturkampf (Shankland 2003, 156-161). Alevi representatives won seats in the Turkish parliament within the ranks of the Republican People's Party (Cumhuriyet Halk Partisi-CHP) or left-wing parties, while standing aloof from bureaucratic positions. To draw a comparative inference with Prussia, while the Catholics generally feared the atheism of the SPD, socially minded Catholic priests (rote Kapläne) also sympathized with the SPD and leftwing ideas. The increase in the state budget for the Diyanet and the construction of Sunni mosques in not only Sunni, but also Alevi, villages was only one of the methods through which the Diyanet promoted a silent Sunnification of Turkey's heterodox Islamic population.

The emergence of Alevism in the public sphere has emerged as an index of the politics of pluralism in Turkey and of the very limits of that sphere (Tambar 2010, 675-676). The 1980-1983 military regime created even more tension between the Turkish state and Alevis by officially endorsing the "Turkish-Islamic Synthesis," which contrary to early republican tenets considered Sunni Islam to be not a hindrance to Turkish modernization but a bedrock of Turkishness (Cetinsaya 1999, 368-376). Mandatory religious education was reintroduced, whereas Alevism was seen as divisive and an obstacle to national cohesion and solidarity, much like Bismarck viewed Catholicism. The instrumentalization of religion and the complete subordination of minority religions and denominations to the official one is a common thread between imperial Prussia and republican Turkey. Nevertheless, the role 
of Sunni Islam for Turkey has been much more debated that the one of Protestantism for Prussia and Germany.

\subsubsection{Persistence of Kulturkampf: the headscarf issue}

Just as in the case of imperial Prussia, aspects of the Kulturkampf referring to state attempts to regulate the public sphere paved the way to highly polarized confrontations. As the public manifestation of religiosity grew into a highly contested issue, the headscarf question became the palladium of a republican Kulturkampf between those who viewed the exclusion of religion from the public sphere as an indispensable element of republican Turkey and those who put forward the public rehabilitation of Islam as an inevitable consequence of Turkey's democratization or simply the resurgence of Turkey's new Islamist elite (Göle 1997, 22). The question whether headscarved female students would be allowed entry to university campuses became a highly debated issue throughout the 1990s and greatly contributed to the growth of Islamist political mobilization (Altınordu 2010, 532-534). The controversy did not dissipate even after the military intervention of 28 February 1997, which took the name "soft coup", and the subsequent ban on the headscarf within university campuses. In 1999, the attempt of Merve Kavakçı, an elected delegate of the Islamist Welfare Party (Refah Partisi-RP) to take headscarved the oath of allegiance to the Republic of Turkey, led to an unprecedented turmoil in the Turkish parliament. Ms. Kavakçı was removed from the plenary hall and was eventually stripped of her parliamentary seat. ${ }^{14}$ Another famous case was that of Leyla Şahin, a medicine student who was not allowed to enter the Istanbul University campus in 1998 without removing her headscarf. Eventually she had to emigrate to Austria where she resumed her university education. Şahin filed an appeal at the European Court of Human Rights (ECtHR) arguing that her religious freedom was violated. In its verdict, the ECtHR stated that these administrative measures did not constitute a violation of the European Convention of Human Rights (ECHR) (European Court of Human Rights (ECtHR) 2004, 27, Altiparmak and Karahanogullari 2006).

About a decade later, the headscarf question remained in the heart of the confrontation between the incumbent Justice and Development Party (AKP) and Turkey's secularist bureaucracy. One of the key arguments of the March 2008 closure case against the AKP was its initiative after its victory in the July 2007 elections to introduce a constitutional amendment to allow for the free public use of the headscarf (Grigoriadis 2009, 1205-1207; Saktanber and Çorbacioğlu 2008, 515). Following the survival of the AKP at the 2008 closure trial and its new electoral victory in 2011 , the question of university headscarf was resolved through a different interpretation of existing regulations. As a series of criminal investigations for alleged coup plots led to the detention of tens of high-level officers, the AKP government strengthened its grip upon the state and the military was deprived of its political influence. While female students were at last free to enter university campuses with

\footnotetext{
14 Kavakçı was later stripped of Turkish citizenship for failing to comply with Turkish citizenship law regulations.
} 
headscarf, religion has remained a key item in the political agenda and an instrument of citizenship politics (Baban 2014a, b, 5-9).

The consolidation of the power of the AKP administration became evident. Yet this raised concerns within the secular segment of the Turkish society regarding an encroachment upon their rights. Allowing for the free use of the headscarf in the public sphere was a necessary but not sufficient condition for the consolidation of human rights protection. On the contrary, it was feared that it would lead to limitations to the human rights of secular Turks. The possibility of holding a secular or heterodox lifestyle in a country, where Sunni Islam acquired a leading role in the country's social and political life appeared to become questionable, especially with reference to new emerging symbolic issues like alcohol consumption in public. ${ }^{15}$ While the ECtHR recognized Alevi parents the right to have their children exempted from mandatory religious education (European Court of Human Rights (ECtHR) 2007), government initiative on reforming religious education curricula in public schools met with the suspicion and the opposition of non-Sunni groups, Alevis, nonMuslims and agnostics (Grigoriadis and Gurcel 2014, 312-322). While it was hoped that the European Union could contribute to the rise of social trust and mutual tolerance, this became less likely due to the dimming prospects of Turkey's EU membership (Aydın-Düzgit and Keyman 2013, 17-18). Rising social polarization made it clear that this new variant of Turkish Kulturkampf could evolve into a major feature of Turkish politics.

\section{Collectivism, individualism and the limits of Kulturkampf}

Guiso et al. (2008) draw their evidence from World Values Survey and the German Socio-Economic Panel and argue that intergenerational transmission of beliefs about the trustworthiness of others is inclined to preserve a low-trust equilibrium in society. Similarly, Alesina and Guliano (2011) find a significant negative correlation between generalized trust and strong family ties, which may explain the limited role of social capital and economic underdevelopment in Catholic rather than in Protestant societies and therefore sets the grounds for the individualism-collectivism dichotomy in our Kulturkampf model.

Comparative historical evidence from Kulturkampf experiences in Imperial Prussia and Republican Turkey implies that different religious institutions reveal different commitment levels toward public authority and therefore are not equally inclined to be integrated into state bureaucracy. In our model that follows, we suggest that Catholic as well Alevi and tarikat-affiliated priests can be defined as collectivist, because they identify with the welfare of their religious institution and its ability to provide social welfare. Similarly, Lutheran and Sunni Hanafi priests prioritize their personal welfare over the welfare of their respective institution and are more

\footnotetext{
15 Consumption of alcohol in public venues has emerged as an additional contentious point between religious conservatives and secularists. As municipal leaders attempted to regulate the use of alcohol in restaurants and bars, there was rising concern that regulation would lead to limitation.
} 
willing to become bureaucrats. Greif's terminology on collectivist and individualist economic systems is extrapolated to explain the different distributive commitments of Catholicism and Lutheranism but also of Alevism and tarikat-affiliated Sunni Islam as well as of Hanafi Sunni Islam (1994). Becker and Wößmann (2009) identify human capital as the channel that links Protestantism rather than Catholicism to economic growth in the lands of Prussia during the nineteenth century. In an extension of Weber's Protestant Ethic, Grigoriadis (2016) argues that Catholicism and tarikat-affiliated Islam are collectivist religions, because in their respective collectives, the monastery and the tarikat, one observes a hierarchical provision of common goods; at the same time, Protestantism is an individualist religion, because horizontal charity and individual self-realization facilitate the preservation of its respective collective.

While Sunni Hanafi Islam came under state grip and most Turkey's imams accepted their role as republican bureaucrats, tarikat-affiliated versions of Sunni Islam and Alevism did not follow the same path. As they proved collectivist and refused to collaborate with the republican state, they faced repression and marginalization. Tarikats and Alevism went underground and survived for decades until the advent of multipartyism and a pluralist public sphere following the 1961 Constitution allowed for their gradual reemergence in the public sphere in the 1960s.

Sunni Hanafi imams were given strong material incentives to join the state institution and propagate its policies. Article 2 of the 1924 Constitution that gave Sunni Islam official religion status was amended in 1928. In 1937, laicism became a constitutional principle following a new amendment of Article 2. Nonetheless, this did not mean that support for the reform was unanimous and unequivocal. As several rebellions in the 1920s and 1930s had—at least in part-religious underpinnings, it was clear that the introduction of laicism as a guiding principle of the Constitution had not been universally accepted by all and that the Kulturkampf lingered on. The struggle continued; in fact, the specter of religious takeover eventually became one of the most enduring themes of republican Turkish politics (Gözaydın 2009, 26). On the contrary, collectivist imams faced severe repression for decades before the introduction of multiparty politics and the opening of the political sphere allowed for the emergence of Turkish political Islam. Since the state had to reduce repression, in the light of political developments tarikat-affiliated resistant collectivist imams would form the backbone of the Turkish political Islam that would challenge the state monopoly over religious affairs. The rise of the "National View" (Milli Görüss) movement by Necmettin Erbakan and the establishment of a series of Islamist parties inspired by the movement principles could be liked to that development. Alevi functionaries, on the other hand, would spearhead the revival of Alevism as religious, cultural and political movement within the Turkish left. The repression of collectivist Alevis contributed to the resurgence of a politicized, distinctively modern Alevi identity in the 1960s in the context of rising political polarization and the emergence of a Turkish center left (ortanın solu) as a considerable political force (Dressler 2008, 285, 2013, 272-279). ${ }^{16}$

\footnotetext{
${ }^{16}$ As Alevi organizations challenged the state-controlled primacy of Sunni Islam (Dressler 2002, 2008, 288-295), the shift of Turkish democracy towards majoritarianism became an additional reason for concern for the country's Alevis.
} 
What we argue with our model is that the success of the Kulturkampf as secularization project is not only contingent upon the repressive capacity of the state, but also mainly upon the prior institutional commitments of the clergymen that are forcibly integrated or about to be expropriated by the state. The transformation of collectivist priests into bureaucrats delineates the long-run measure of Kulturkampf success, while the active politicization of individualist priests in the aftermath of their bureaucratic incorporation constitutes its short-run equivalent. Without the recruitment of individualist priests, the Kulturkampf fails in its initial premises. Without the participation of collectivist priests, there are continuous problems of legitimacy and anti-government mobilization. Hence, while our model provides static equilibrium solutions, it also includes powerful implications for dynamic policy outcomes.

\section{The model}

We define Kulturkampf as a secularization game with two players: the executive (E) and the priest $(\mathrm{P})$. The executive wants to transform priests into bureaucrats and for that reason it offers them a wage $w_{t}^{E}$, where $\mathrm{t}$ denotes the game period. The priest can choose to accept the wage and become a bureaucrat or remain loyal to the church and receive both wage $w^{C}$ and satisfaction from the social activity of the church such that $\kappa \frac{d_{C}}{1-\phi}$, where $\kappa$ is a parameter denoting the significance of social distribution for the priest, $d_{C}$ is the average social distribution performed by the church and $\phi$ is the percentage of wealthy people in society.

Priests are either collectivist or individualist: collectivist priests care about social distribution by the church rather than their personal welfare, whereas the reverse holds for individualist priests. These privately observed types are denoted as $\mu \in\{0,1\}$, where $\mu=1$ when the priest is collectivist and $\mu=0$ when the priest is individualist. The sequence of the moves is as follows:

1. E chooses the first-period wage $w_{1}^{E}$ and the first-period repression technology $r_{1}^{E}$.

2. P learns his type $\mu$ revealed by nature.

3. $\mathrm{P}$ chooses to become a bureaucrat or retain his position in the church.

4. E chooses the second-period wage $w_{2}^{E}$ and the second-period repression technology $r_{2}^{E}$.

5. $\mathrm{P}$ chooses whether he will become a politician or not in period 2 .

After he has accepted to become a bureaucrat or remain in the church, the priest can actively defend the interests of the organization he represents by entering politics or staying indifferent. The utility function of the executive in period 1 has the following form:

$$
V_{1}^{E}\left(w_{1}^{E}, r_{1}^{E} ; w_{C}, d_{C}\right)=\pi_{1}^{E}\left(w_{1}^{E}, r_{1}^{E} ; w_{C}, d_{C}\right)-K_{1}^{E}\left(w_{1}^{E}, r_{1}^{E} ; w_{C}, d_{C}\right)
$$


where $K_{1}^{E}$ is the cost of secularization in period 1 and $\pi_{1}^{E}$ is the profit of secularization for the government such that $\pi_{1}^{E}=\left\{\begin{array}{c}\ln r_{1}^{E} \text { if } \mu=1 \\ \ln w_{1}^{E} \text { if } \mu=0\end{array}\right.$. The priest can be collec-

tivist with probability $f$ or individualist with probability $1-f$. The payoff of the bureaucracy is transformed as follows: $V_{1}^{E}\left(w_{1}^{E}, r_{1}^{E} ; w_{C}, d_{C}\right)=$ $f\left[\ln r_{1}^{E}-L_{1}^{E}\left(r_{1}^{E} ; d_{C}\right)\right]+(1-f)\left[\ln w_{1}^{E}-M_{1}^{E}\left(w_{1}^{E} ; w_{C}\right)\right]$, where L denotes the secularization cost for collectivist priests and $M$ the secularization cost for individualist priests. It is clear that individualist priests can be attracted with material resources, whereas collectivist priests can be coerced with repression by the executive. The payoff for the priest in period 1 is given by the following function:

$$
V_{1}^{P}=g_{1}+\mu \psi_{1}+(1-\mu) w_{1} \text {, where } \psi_{1} \in\left\{r_{1}^{E}, \kappa \frac{d_{c}}{1-\phi}\right\} \text { and } w \in\left\{w_{1}^{E}, w_{C}\right\} \text {. }
$$

This can be rewritten as:

$$
V_{1}^{P}= \begin{cases}\frac{r_{1}^{E}}{1-q}, & \text { if } \mu=1 \text { and } \frac{r_{1}^{E}}{1-q} \geq \kappa \frac{d_{C}}{1-\phi} \\ \kappa \frac{d_{C}}{1-\phi}, & \text { if } \mu=1 \text { and } \frac{r_{1}^{E}}{1-q}<\kappa \frac{d_{C}}{1-\phi} \\ w_{1}^{E}, & \text { if } \mu=0 \text { and } w_{1}^{E} \geq w_{C} \\ w_{C}, & \text { if } \mu=0 \text { and } w_{1}^{E}<w_{C}\end{cases}
$$

where $\mathrm{q}$ is the share of ecclesiastical property confiscated by the state. We assume that $w_{2}^{E}=w_{1}^{E}+s$ and $r_{2}^{E}=r_{1}^{E}+y$, where $\mathrm{s}$ and $\mathrm{y}$ are bonus parameters for individualist and collectivist priests, respectively, such that $y \geq s$. In period 2 , the payoffs of the executive and the priest have the following form:

$$
\begin{gathered}
V_{2}^{E}\left(w_{2}^{E}, r_{2}^{E} ; w_{C}, d_{C}\right)=\tau\left[f \ln r_{2}^{E}+(1-f) \ln w_{2}^{E}\right]+(1-\tau)\left[f \ln r_{1}^{E}+(1-f) \ln w_{1}^{E}\right] \\
V_{2}^{P}=\left\{\begin{array}{cc}
\frac{r_{2}^{E}}{1-q}, \quad \text { if } \mu=1 \text { and } \frac{r_{2}^{E}}{1-q} \geq \frac{r_{1}^{E}}{1-q} \Rightarrow y \geq 0 \\
\frac{r_{1}^{E}}{1-q}, \quad \text { if } \mu=1 \text { and } \frac{r_{2}^{E}}{1-q}<\frac{r_{1}^{E}}{1-q} \Rightarrow y<0 \\
w_{2}^{E}, \quad \text { if } \mu=0 \text { and } w_{2}^{E} \geq w_{1}^{E} \Rightarrow s \geq 0 \\
w_{1}^{E}, \quad \text { if } \mu=0 \text { and } w_{2}^{E}<w_{1}^{E} \Rightarrow s<0
\end{array}\right.
\end{gathered}
$$

It becomes obvious that in period 2 the executive can choose wages and repression technologies only for those priests who decided to become secularized in period 1. The bureaucracy wants its priests to be politically active and defend the legitimacy of state policies in representative bodies. Priests continue to preserve their type also in period 2. Both types can enter or abstain from politics. The difference between collectivist and individualist priests is that individualist priests require a 
higher wage to cooperate in period 2 whereas collectivist priests will cooperate only if they observe a lower level of repression. If they decide not to cooperate, individualist priests receive the same payoff they received in period 1. The current payoff for E given the two-period structure of the game has the following form:

$$
\begin{aligned}
& V^{E}\left(w_{1}^{E}, r_{1}^{E} ; w_{C}, d_{C}\right)=V_{1}^{E}+\delta V_{2}^{E}=f\left[\ln r_{1}^{E}-L_{1}^{E}\left(r_{1}^{E} ; d_{C}\right)\right] \\
& \quad+(1-f)\left[\ln w_{1}^{E}-M_{1}^{E}\left(w_{1}^{E} ; w_{C}\right)\right]+\delta\left[\tau f \ln r_{2}^{E}+\tau(1-f) \ln w_{2}^{E}\right] \\
& \quad+(1-\tau)\left[f \ln r_{1}^{E}+(1-f) \ln w_{1}^{E}\right]
\end{aligned}
$$

The levels of wage and repression imposed by the executive in both periods rise with the wage offered to priests by the church and the level of social distribution in society. Although the church does not have the institutional means to counter the disciplinary and enforcement agencies of the state, its ability to finance the wages of priests and provide social welfare to poorer people in society make it a critical part of the Kulturkampf game.

Proposition 1 Collectivist priests prefer to join the state bureaucracy rather than stay in the church if and only if $\frac{r_{1}^{E}}{1-q} \geq \kappa \frac{d_{C}}{1-\phi}$ and $\frac{\partial^{2} L_{1}^{E}\left(r_{1}^{E} ; d_{C}\right)}{\partial r_{1}^{E} \partial d_{C}}<0$ such that $\frac{\partial r_{1}^{E}}{\partial d_{C}} \geq 0$.

Proof of Proposition 1 See the "Appendix".

Corollary 1 Individualist priests prefer to join the state bureaucracy rather than stay in the church if and only if $w_{1}^{E} \geq w_{C}$ and $\frac{\partial^{2} M_{1}^{E}\left(w_{1}^{E} ; w_{C}\right)}{\partial w_{1}^{E} \partial w_{C}}<0$ such that $\frac{\partial w_{1}^{E}}{\partial w_{C}} \geq 0$.

Proof of Corollary 1 See the "Appendix".

Collectivist priests are harder to secularize than individualist priests such that $\frac{\partial^{2} L_{1}^{E}\left(r_{1}^{E} ; d_{C}\right)}{\partial r_{1}^{E} \partial d_{C}} \geq \frac{\partial^{2} M_{1}^{E}\left(w_{1}^{E} ; w_{C}\right)}{\partial w_{1}^{E} \partial w_{C}}$. Thus, successful secularization implies that $\frac{\partial r_{1}^{E}}{\partial d_{C}} \leq \frac{\partial w_{1}^{E}}{\partial w_{C}}$. A rigid commitment to the church as a social welfare provider suggests that the bureaucracy is likely to invest more in efficient wage provision rather than the imposition of disciplinary measures. Historical evidence from the Kulturkampf between 1871 and 1878 suggests that the prioritization of repression over material benefits has not been an efficient choice for the Prussian government and facilitated the political mobilization of the Catholic Center in Prussian and German legislative politics. Similarly, the prioritization of repression over material benefits also contributed to the emergence of Turkish political Islam in the 1960s and its gradual rise to a hegemonic position in Turkish politics. In both cases, secularization proved less successful than its initiators had hoped.

Proposition 2 Secularized collectivist priests are inclined to enter politics and support the church policies of the government if and only if $y \geq 0$ and $\frac{1}{\tau} \geq r_{1}^{E}-y$.

Proof of Proposition 2 See the "Appendix". 
Corollary 2 Secularized individualist priests are inclined to enter politics and support the church policies of the government if and only if $s \geq 0$ and $\frac{1}{\tau} \geq w_{1}^{E}-s$.

\section{Proof of Corollary 2 See the "Appendix".}

Since $\frac{\partial r_{1}^{E}}{\partial d_{C}} \leq \frac{\partial w_{1}^{E}}{\partial w_{C}}$ holds for both periods of the game, the bureaucracy can afford to provide a lower bonus to individualist bureaucrats. Their wage in period 1 increases with their initial endowment $w_{c}$ and they therefore need less additional motivation to become religious activists in favor of the state and consequently against the church. Conversely, collectivist bureaucrats expect a higher bonus because their period 1 payoff increases comparatively less with their initial endowment $\kappa \frac{d_{C}}{1-\phi}$. As the experience of Kulturkampf shows, the most successful advocates of Bismarckian church policies and the Kemalist secularization reform were state priests and higher-level clergymen that allied with the government. The more Catholic, tarikat-affiliated Sunni and Alevi clergy were involved in politics in favor of secularism, the more likely it was for secularism to consolidate.

The static equilibria proposed above indicate that rational government bureaucracies pursue a dual set of strategies (repression technologies and material rewards) for two different types of priests: collectivist and individualist. In the Prussian case, Catholic priests can be designated as collectivist priests while Protestant priests, individualist; in the Turkish case, the tarikat-affiliated Sunni and Alevi priests can be designated as collectivist while the mainstream Diyanet-employed Hanafi Sunni priests, individualist. The transformation of collectivist priests into civil servants is costlier for the government than the transformation of individualist priests. The politicization of priests recruited by the government is the best guarantee for the long-term sustainability of the equilibria observed in the Kulturkampf game; from the executive's perspective, the key here is to involve collectivist priests (Catholic, tarikat-affiliated Sunni or Alevi) and have them aligned with its own religious policies. This explains the degree of state repression against collectivist priests who openly disavowed state policies on religion in both imperial Prussia and Turkey, as well as the limits of the success of secularization policies. Both in Prussia and Turkey, the Kulturkampf failed to incorporate both types of priests into government bureaucracies.

\section{The challenge of multiculturalism and integration in Germany and beyond}

As the Catholic-Protestant divide has lost most of its meaning today following the secularization of German society, Germany is facing a new cultural challenge. The question of integrating Germany's Muslim immigrants has become one of the key domestic politics items, acquiring proportions that could only be compared with the late nineteenth century Kulturkampf. The dilemma for the German government is now different. While bureaucratic assimilation to the dominant model of church-state relations on the one hand and state repression on the other 
are offered as options to Islamic priests in Germany, the challenge is wider. It has to do with the willingness of the German government to advance multiculturalism in the public sphere and therefore institute the public manifestation of Islamic norms in spaces dominated by Christian-Protestant or Catholic_or secularbut Christian-influenced-majorities. Cases of bodily religious practices such as the headscarf and male circumcision, or even the ritual slaughter of animals and the institution of halal food, have attracted considerable media attention, raised a public debate about the character as well as the limits of German multiculturalism and reminded of the legacy of Kulturkampf in contemporary German politics.

The entanglement of national and transnational notions of citizenship has been linked with identity symbols and the diffusion of cultural norms among various groups of Muslim and particularly Turkish immigrants in postwar Germany. Hence, the use of headscarf in the public sphere and male circumcision suggest defining elements of family values and transnational connectedness between the sending (Turkey) and the receiving country (Germany) (Soysal 2007, 517-522). As Islam has not been a formative element of German nation-building and identity, Kulturkampf here refers both to the homogenization of urban social spaces based on Christian or Christian-inspired "secular" values and to the co-optation of religious personnel with a bureaucratized state structure. While the enforcement of Protestant or Catholic norms occurs again through bureaucratic channels (courts, state legislatures or executives), its proclaimed purpose is not explicitly religious, but linked to public order and majority-minority relations from the perspective of human rights. Furthermore, the existence of Islamic organizations in Germany such as the Islamrat, the Zentralrat, the Diyanet-affiliated TurkishIslamic Union for Religious Affairs (Türkisch-Islamische Union der Anstalt für Religion e.V.-Diyanet Işleri Türk-Islam Birliği-DITIIB) and the German Islam Conference have compensated for the absence of Islamist political mobilization and transformed the integration of Muslims into German society into an interest groups question (Dolezal et al. 2010, 176). Furthermore, the problematic status of Islam as an official religion in Germany combined with convert alerts proposed by CDU politicians in the 2000s as a result of Germany's joining the international coalition against terrorism imply that there has been a continuous commitment by conservative German administrations to maintain restrictions against Islam at the civil society level (Özyürek 2009, 96-99). Hence, the question of Muslim integration into German society would not become part of a central political agenda, as the creation of Islamic universities or specialized chairs would suggest.

The decision of the German Constitutional Court in 2003 on the right of Fereshta Ludin, a Muslim school teacher, to wear the headscarf in classroom indicated the boundaries of German institutional tolerance toward religious difference. The court stated that the Muslim school teacher could wear the headscarf in the classroom without losing her job on that ground, but, in the absence of a statutory basis, it recommended that regional governments (Landesregierungen) should fill the legal void (Amir-Moazami 2005, 268-270). It was the case that the legal enforcement of state neutrality toward religion was perceived differently by many German states; regional governments run by center-right parties usually included exemptions for Christian and Jewish symbols and thus transformed state neutrality into state bias against 
religious minorities and particularly Muslims (Kars 1934, 60-63). The Baden-Württemberg law on state education mentions explicitly in paragraph 38 , sentence 3 that "Christian and Occidental values or traditions correspond to the educational mandate of the Land constitution" and this provision is not treated as contradictory to the order of the Federal Constitutional Court.

Hence, continuities of the Kulturkampf tradition in contemporary German and European politics are linked with judicial rule-making and legal interpretation at the subnational level. In the headscarf case, the federal government confirmed its adherence to the principle of state neutrality toward individual religious preferences, but it delegated authority to state governments for their protection. The legal steps undertaken by the majority of state governments in the direction of religious freedom consolidated the incumbency advantage of the popular majority and the treatment of Christian values as baseline principles for state organization and the delivery of public goods such as education. While this set of measures has not altered the commitment of the federal government to human rights protection and the provision of equal opportunities to all citizens, it has revealed a significant tradeoff between multicultural equality and asymmetric federalism, which becomes particularly acute in the German context. The modern definition of Kulturkampf does not entail the use of state violence with the purpose of institutional assimilation into the structures and principles of Protestantism. Its main aim is not to exert direct effects on the formation of religious preferences and the constitutional protection of human rights. On the contrary, it imposes decentralized administrative and judicial barriers on the members of a religious minority, whose social traditions and daily practices diverge significantly from the normative preferences of the majority.

The prohibition of male circumcision by a Cologne court in May 2012 and its uplifting by both bodies of the German legislature, the Bundesrat and the Bundestag, in November and December 2012, provided another instance of this tradeoff between multiculturalism and asymmetric federalism (Merkel and Putzke 2013, 444-447). First, it suggested that the institutional treatment of religious differences could occur not only in education or family practices, but also in public health. Moreover, civic integration policies adopted in recent years by state governments revealed a dichotomy between Rawlsian and repressive liberalism; the Baden-Württemberg Gesprächsleitfaden for the evaluation of citizenship applications positioned Islam in radical contrast with everything that a liberal state and society represent (Joppke 2007, 14-16).

These debates were intensified throughout the West at the outset of the refugee crisis that has brought millions of Syrian, Iraqi, Afghan and other asylum seekers to Germany and other EU member states. The sharp rise of far-right anti-immigrant parties even in countries with a solid liberal tradition manifested the limits of the appeal of official integration policies and multiculturalism to a substantial part of the European precariat. The ability of European states to accommodate such high numbers of refugees within their welfare state was intensely debated, alongside the duties of refugees to respect the normative codes of their destination countries. Similarly, in the United States, anxiety and concerns about rising immigration and their own economic future fueled far-right-wing political mobilization and helped the election of Donald Trump as US President. Measures such as anti-refugee laws, 
travelling restrictions to the citizens of several Muslim-majority states, and the planned construction of a wall along the US-Mexican border, manifest the proliferation of an anti-multiculturalist and anti-immigrant discourse across the Atlantic.

It becomes obvious that the corrective ability of federal institutions, as it has been the case in the male circumcision debate, is not sufficient to prevent instances of state- or local-level interpretations of state commitment to religious neutrality that constrain the religious freedom of Muslims in Germany and the European Union. If secularization in Bismarck's Kulturkampf was the institutional cooptation of the Catholic Church by the Prussian government and the introduction of the Protestant model in the relationship of the royal government with the Catholic Church, then its modern derivative can be defined as the imposition of liberal norms primarily against Muslims. Evidence from the aforementioned cases suggests that their de jure integration is not likely to be without repercussions, while their de facto integration to European societies and its central institutions is much further away from any optimal point of multicultural coexistence and equality.

\section{Conclusions}

The transition from a theocratic state or a state infused by powerful religious authorities to a secularist state that declares its commitment to full subordination of religious institutions, bureaucratization of religious personnel and official status for the majority religion has been a common feature of several modernization projects. The abolition of all formal and informal religious institutional structures independent of the state, the bureaucratization of religious personnel and the rise of the dominant religion to official status were objectives of state authorities in both imperial Prussia and republican Turkey, as well as key elements in the state-building experience of several states in the nineteenth and twentieth century. Imperial Prussia and republican Turkey comprise an interesting dyad in this respect. This study has underscored key similarities in the orientation as well as in the limitations of two projects implemented under very different historical and cultural circumstances. Catholicism, tarikat-affiliated Sunni and Alevi Islam were considered as obstacles to the successful completion of the respective modernization projects. Hence their respective religious leaders who refused to trade material benefits for their allegiance to the state faced severe repression. In that case, resistance puts limits on the success of the secularization project and paves the way for its challenge at the public sphere level when political circumstances permit.

It is also important to stress the divergent modernization experiences of the two states. The Prussian modernization process culminated in the German Empire and paved the ground for Germany's disastrous involvement in two World Wars, the rise of Nazi totalitarianism and Cold War-era divisions. Nevertheless, West Germany established a consolidated federal democracy and even achieved reunification with the East. Its phenomenal economic growth involved the arrival of millions of immigrants, which in turn paved the ground for a reformulation of the Kulturkampf along new dividing lines. The Turkish modernization process has had a mixed and uneven record, and the Kulturkampf has often been one of its defining features. While a multi-party system was introduced at the outset of the Second World War, 
democratic consolidation was not completed, as the secularist state elite feared that the conservative majority would question the republican achievements once in power. State attempts to control religion and the resistance of unofficial Islam against its subordination set the framework of a Kulturkampf which lasted until 2002, when the Justice and Development Party (Adalet ve Kalkınma Partisi-AKP) rose to power. The rise of the AKP, a party coming from the Islamist political tradition raised optimism that Turkey's democratic consolidation would be achieved by a conservative political actor. Nevertheless, a shift in the AKP government policies pointed that Turkey's democracy would drift towards competitive authoritarianism. The AKP government was eventually able to control the state and reverse the terms of Kulturkampf. The Islamization of Turkish public sphere and the delegitimization of secularist lifestyle as "foreign" or "incompatible with traditional values" has become the object of the latest version of the Turkish Kulturkampf.

In our game-theoretic model, collectivist priests care about the social welfare activity of their religious organization and can be attracted only with repression. Individualist priests only care about their personal welfare and can be attracted only by the provision of a higher wage. We find that that collectivist priests are harder to recruit than individualist ones, because the cost of recruitment of the former is higher and their payoff lower. For this reason, the bureaucracy needs to provide them with a higher bonus in period 2 if it wants them to actively defend its ecclesiastical agenda in representative institutions. The lower the bonus that a bureaucracy decided to give to any type of priests, the less likely these are to increase their loyalty to the state. Successful state policies imply the recruitment of collectivist priests and their active politicization in favor of the executive's religious agenda. However, neither imperial Prussia nor republican Turkey succeeded in monopolizing political manifestations of religion in the public sphere. The success of political Catholicism and political Islam in becoming considerable political forces in imperial Prussia and republican Turkey, respectively, limited the success of repressive state recruitment policies, with the politicization of some collectivist priests outside the state realm and against the executive's religious agenda proving critical for the outcome of the Kulturkampf in these two states. Recruiting individualist priests through material benefits and collectivist priests through repression proved insufficient for the complete victory of the state and the absolute success of secularization policies. Secularization was therefore challenged at the political and social level when the conditions became ripe.

Both Kulturkampfs have left a mixed legacy straddling the period from the late nineteenth century to date. Despite a forceful — and at times violent - secularization process, which has taken place under divergent social circumstances, they have led to comparable conclusions and influence politics decades later. The elimination of the role of religion in identity politics and the public sphere has not been achieved. Identity debates that emanate from the question of integration of Germany's immigrant population and the building of a multicultural German identity, in particular with reference to the role of Islam in German society, echo many of the arguments that arose in the context of Protestant-Catholic polarization. In the case of Turkey, the Kulturkampf has remained alive due to the changing fortunes of Turkish political Islam and confrontations concerning the position of Sunni Islam in the public sphere and the difficulties in establishing a liberal consensus between the secular and the Islamic conservative 
segments of Turkey's society. Our game-theoretical model contributes to the identification of the impact of factors that have contributed to the particular constellation of state-religion relations. Thus, a comparative analysis of Kulturkampf and its effects on the Prussian and Turkish states contributes to a better understanding of secularist transformation in the context of top-down modernization and to a more comprehensive search for the conditions of social consensus in diverse cultural contexts. It also invites further research on the comparative study of religious mobilization.

\section{Appendix}

\section{Proof of Proposition 1}

We provide the first-order conditions for the executive:

$$
\begin{aligned}
\max _{w_{1}^{E}, r_{1}^{E}} V^{E}\left(w_{1}^{E}, r_{1}^{E} ; w_{C}, d_{C}\right)= & {\left[\begin{array}{l}
(1-f)\left[\frac{1}{w_{1}^{E}}-\frac{\partial M_{1}^{E}\left(w_{1}^{E} ; w_{C}\right)}{\partial w_{1}^{E}}\right]+\delta(1-f)\left[\frac{\tau}{w_{1}^{E}+s}+\frac{1-\tau}{w_{1}^{E}}\right] \\
f\left[\frac{1}{r_{1}^{E}}-\frac{\partial L_{1}^{E}\left(r_{1}^{E} ; d_{C}\right)}{\partial r_{1}^{E}}\right]+\delta f\left[\frac{\tau}{r_{1}^{E}+y}+\frac{1-\tau}{r_{1}^{E}}\right]
\end{array}\right] } \\
= & {\left[\begin{array}{l}
0 \\
0
\end{array}\right]=U^{E}\left(w_{1}^{E}, r_{1}^{E} ; w_{C}, d_{C}\right) }
\end{aligned}
$$

Using the implicit function theorem, we define the second-order conditions for the executive such that:

$$
=\left[\begin{array}{cc}
D_{w_{1}^{E}, r_{1}^{E}} U^{E}\left(w_{1}^{E}, r_{1}^{E} ; w_{C}, d_{C}\right) & 0 \\
-(1-f)\left[\frac{1}{\left(w_{1}^{E}\right)^{2}}+\frac{\partial^{2} M_{1}^{E}\left(w_{1}^{E} ; w_{C}\right)}{\partial w_{1}^{E 2}}\right] & \\
-\delta(1-f)\left[\frac{\tau}{\left(w_{1}^{E}+s\right)^{2}}+\frac{1-\tau}{\left(w_{1}^{E}\right)^{2}}\right] & -f\left[\frac{1}{\left(r_{1}^{E}\right)^{2}}+\frac{\partial^{2} L_{1}^{E}\left(r_{1}^{E} ; d_{C}\right)}{\partial r_{1}^{E 2}}\right] \\
0 & \left.-\delta f \frac{\tau}{\left(r_{1}^{E}+y\right)^{2}}+\frac{1-\tau}{\left(r_{1}^{E}\right)^{2}}\right]
\end{array}\right]
$$

$D_{w_{C}, d_{C}} U^{E}\left(w_{1}^{E}, r_{1}^{E} ; w_{C}, d_{C}\right)$

$$
=\left[\begin{array}{cc}
-(1-f)\left[\frac{1}{\left(w_{1}^{E}\right)^{2}} \frac{\partial w_{1}^{E}}{\partial w_{C}}+\frac{\partial^{2} M_{1}^{E}\left(w_{1}^{E} ; w_{C}\right)}{\partial w_{1}^{E} \partial w_{C}}\right] & 0 \\
-\delta(1-f)\left[\frac{\tau}{\left(w_{1}^{E}+s\right)^{2}} \frac{\partial w_{1}^{E}}{\partial w_{C}}+\frac{1-\tau}{\left(w_{1}^{E}\right)^{2}} \frac{\partial w_{1}^{E}}{\partial w_{C}}\right] & -f\left[\frac{1}{\left(r_{1}^{E}\right)^{2}} \frac{\partial r_{1}^{E}}{\partial d_{C}}+\frac{\partial^{2} L_{1}^{E}\left(r_{1}^{E} ; d_{C}\right)}{\partial r_{1}^{E} \partial d_{C}}\right] \\
0 & -\delta f\left[\frac{\tau}{\left(r_{1}^{E}+y\right)^{2}} \frac{\partial r_{1}^{E}}{\partial d_{C}}+\frac{1-\tau}{\left(r_{1}^{E}\right)^{2}} \frac{\partial r_{1}^{E}}{\partial d_{C}}\right]
\end{array}\right]
$$


The comparative statics of the executive and the church are essential in order to identify the secularization and politicization conditions for both types of priests, collectivist and individualist. Completing the implicit function theorem for the executive, we find:

$$
\begin{aligned}
& -D_{w_{1}^{E}, r_{1}^{E}} U^{E}\left(w_{1}^{E}, r_{1}^{E} ; w_{C}, d_{C}\right)^{-1} * D_{w_{C}, d_{C}} U^{E}\left(w_{1}^{E}, r_{1}^{E} ; w_{C}, d_{C}\right)=\left[\begin{array}{cc}
\frac{\partial w_{1}^{E}}{\partial w_{C}} & \frac{\partial w_{1}^{E}}{\partial d_{C}} \\
\frac{\partial r_{1}^{E}}{\partial w_{C}} & \frac{\partial r_{1}^{E}}{\partial d_{C}}
\end{array}\right]=\left[\begin{array}{cc}
\frac{\partial w_{1}^{E}}{\partial w_{C}} & 0 \\
0 & \frac{\partial r_{1}^{E}}{\partial d_{C}}
\end{array}\right] \\
& \Rightarrow-D_{w_{1}^{E}, r_{1}^{E}} U^{E}\left(w_{1}^{E}, r_{1}^{E} ; w_{C}, d_{C}\right)^{-1} * D_{w_{C}, d_{C}} U^{E}\left(w_{1}^{E}, r_{1}^{E} ; w_{C}, d_{C}\right)
\end{aligned}
$$

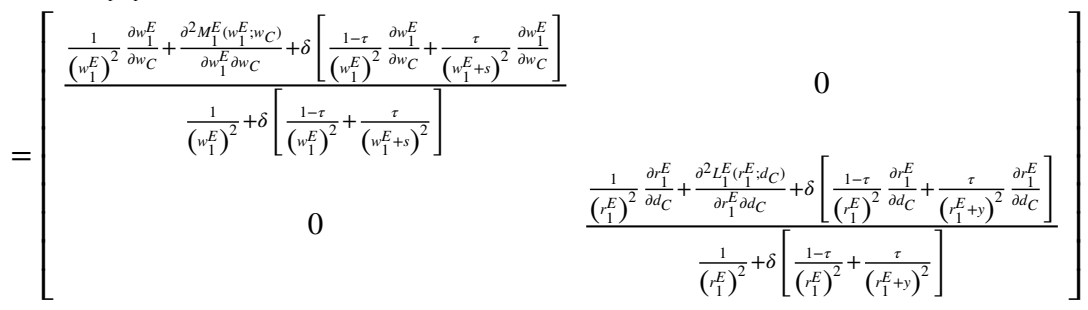

Thus, we provide the following solutions:

$$
\begin{gathered}
\frac{\partial w_{1}^{E}}{\partial w_{C}}=\frac{\frac{1}{\left(w_{1}^{E}\right)^{2}} \frac{\partial w_{1}^{E}}{\partial w_{C}}+\frac{\partial^{2} M_{1}^{E}\left(w_{1}^{E} ; w_{C}\right)}{\partial w_{1}^{E} \partial w_{C}}+\delta\left[\frac{1-\tau}{\left(w_{1}^{E}\right)^{2}} \frac{\partial w_{1}^{E}}{\partial w_{C}}+\frac{\tau}{\left(w_{1}^{E}+s\right)^{2}} \frac{\partial w_{1}^{E}}{\partial w_{C}}\right]}{\frac{1}{\left(w_{1}^{E}\right)^{2}}+\delta\left[\frac{1-\tau}{\left(w_{1}^{E}\right)^{2}}+\frac{\tau}{\left(w_{1}^{E}+s\right)^{2}}\right]} \\
\frac{\partial r_{1}^{E}}{\partial d_{C}}=\frac{\frac{1}{\left(r_{1}^{E}\right)^{2}} \frac{\partial r_{1}^{E}}{\partial d_{C}}+\frac{\partial^{2} L_{1}^{E}\left(r_{1}^{E} ; d_{C}\right)}{\partial r_{1}^{E} \partial d_{C}}+\delta\left[\frac{1-\tau}{\left(r_{1}^{E}\right)^{2}} \frac{\partial r_{1}^{E}}{\partial d_{C}}+\frac{\tau}{\left(r_{1}^{E}+y\right)^{2}} \frac{\partial r_{1}^{E}}{\partial d_{C}}\right]}{\frac{1}{\left(r_{1}^{E}\right)^{2}}+\delta\left[\frac{1-\tau}{\left(r_{1}^{E}\right)^{2}}+\frac{\tau}{\left(r_{1}^{E}+y\right)^{2}}\right]}
\end{gathered}
$$

We solve for $\frac{\partial w_{1}^{E}}{\partial w_{C}}$ such that:

$$
\begin{gathered}
-\frac{\partial^{2} M_{1}^{E}\left(w_{1}^{E} ; w_{C}\right)}{\partial w_{1}^{E} \partial w_{C}}=\frac{\partial w_{1}^{E}}{\partial w_{C}} 2\left[\frac{1}{\left(w_{1}^{E}\right)^{2}}+\delta\left[\frac{1-\tau}{\left(w_{1}^{E}\right)^{2}}+\frac{\tau}{\left(w_{1}^{E}+s\right)^{2}}\right]\right] \\
\Rightarrow \frac{\partial w_{1}^{E}}{\partial w_{C}}=\frac{-\frac{\partial^{2} M_{1}^{E}\left(w_{1}^{E} ; w_{C}\right)}{\partial w_{1}^{E} \partial w_{C}}}{2\left[\frac{1}{\left(w_{1}^{E}\right)^{2}}+\delta\left[\frac{1-\tau}{\left(w_{1}^{E}\right)^{2}}+\frac{\tau}{\left(w_{1}^{E}+s\right)^{2}}\right]\right]} .
\end{gathered}
$$


Similarly, for $\frac{\partial r_{1}^{E}}{\partial d_{C}}$ :

$$
\begin{gathered}
-\frac{\partial^{2} L_{1}^{E}\left(r_{1}^{E} ; d_{C}\right)}{\partial r_{1}^{E} \partial d_{C}}=\frac{\partial r_{1}^{E}}{\partial d_{C}} 2\left[\frac{1}{\left(r_{1}^{E}\right)^{2}}+\delta\left[\frac{1-\tau}{\left(r_{1}^{E}\right)^{2}}+\frac{\tau}{\left(r_{1}^{E}+y\right)^{2}}\right]\right] \\
\Rightarrow \frac{\partial r_{1}^{E}}{\partial d_{C}}=\frac{-\frac{\partial^{2} L_{1}^{E}\left(r_{1}^{E} ; d_{C}\right)}{\partial r_{1}^{E} \partial d_{C}}}{2\left[\frac{1}{\left(r_{1}^{E}\right)^{2}}+\delta\left[\frac{1-\tau}{\left(r_{1}^{E}\right)^{2}}+\frac{\tau}{\left(r_{1}^{E}+y\right)^{2}}\right]\right]} .
\end{gathered}
$$

Proof of Corollary 1 It follows from the proof of proposition 1.

Proof of Proposition 2 We have assumed before that $y \geq s$, which implies that collectivist priests that have joined the state require a higher bonus in order to enter politics and support the religious policies of the government. Hence, it is obvious why $s \geq 0$ and $y \geq 0$ : both types of priests have no incentive to undertake the cost of their political exposure if their payoff is not higher than their fallback payoff, which they earned in period 1. Furthermore, we take the conditions $\frac{\tau}{\left(r_{1}^{E}+y\right)^{2}} \geq 1$ and $\frac{\tau}{\left(w_{1}^{E}+s\right)^{2}} \geq 1$ suggesting that $\left[[1+\delta(1-\tau)] \frac{1}{\left(r_{1}^{E}\right)^{2}}+\delta \frac{\tau}{\left(r_{1}^{E}+y\right)^{2}}\right] \geq 1$ and $\left[[1+\delta(1-\tau)] \frac{1}{\left(w_{1}^{E}\right)^{2}}+\delta \frac{\tau}{\left(w_{1}^{E}+s\right)^{2}}\right] \geq 1$ given that $s, y \geq 0, w_{1}^{E}, r_{1}^{E} \in \mathbb{N}$. The lower the bonus that the government decides to give to both types of priests, the lower the probability that priests will opt for political involvement.

Proof of Corollary 2 It follows from the proof of Proposition 2.

\section{References}

Alesina, A., \& Guliano, P. (2011). Family ties and political participation. Journal of the European Economic Association, 9(5), 817-839.

Altınordu, A. (2010). The politicization of religion: Political Catholicism and political Islam in comparative perspective. Politics \& Society, 38(4), 517-551. https://doi.org/10.1177/0032329210381238.

Altiparmak, K., \& Karahanogullari, O. (2006). European Court of Human Rights: After Şahin: The debate on headscarves is not over, Leyla Şahin v. Turkey, Grand Chamber Judgment of 10 November 2005, Application No. 44774/98. European Constitutional Law Review, 2(2), 268-292.

Amir-Moazami, S. (2005). Muslim challenges to the secular consensus: A German case study. Journal of Contemporary European Studies, 13(3), 267-286.

Anderson, M. L. (1986). The Kulturkampf and the course of German history. Central European History, 19(01), 82-115. https://doi.org/10.1017/S0008938900019154.

Anderson, M. L., \& Barkin, K. (1982). The myth of the Puttkamer purge and the reality of the Kulturkampf: Some reflections on the historiography of Imperial Germany. The Journal of Modern History, 54(4), 647-686. 
Aydın-Düzgit, S., \& Keyman, E. F. (2013). EU-Turkey relations and the stagnation of Turkish Democracy. In S. Aydın-Düzgit, A. Duncker, D. Huber, E. F. Keyman, \& N. Tocci (Eds.), Global Turkey in Europe: Political, economic, and foreign policy dimensions of Turkey's evolving relationship with the EU (pp. 103-164). Rome: Istituto Affari Internazionali (IAI).

Ayhan, H. (1999). Türkiye'de Din Eğitimi. İstanbul: Marmara Üniversitesi İlahiyat Fakültesi Vakfı.

Baban, F. (2014). Secular spaces and religious representations: reading the headscarf debate in Turkey as citizenship politics. Citizenship Studies (ahead-of-print):1-17.

Baban, F. (2014b). Secular spaces and religious representations: reading the headscarf debate in Turkey as citizenship politics. Citizenship Studies, 18(6-7), 644-660.

Baltacı, C. (1993). Türk Eğitim Sisteminin Tarihi Gelişimi. In İ. M. Vakfı (Ed.), Türkiye'de Din Ĕ̆itimi ve Ögrretimi. İstanbul: Güzel Sanatlar Matbaası.

Becker, S. O., \& Wößmann, L. (2009). Was Weber wrong? A human capital theory of protestant economic history. The Quarterly Journal of Economics, 124(2), 531-596.

Berkes, N. (1964). The development of secularism in Turkey. Montreal: McGill University Press. microform.

Berman, E. (2000). Sect, subsidy and sacrifice: An economist's view of ultra-orthodox Jews. Quarterly Journal of Economics, 115(3), 905-953.

Böhm, W. (1891). Fürst Bismarck als Redner: Vollständige Sammlung der parlamentarischen Reden Bismarcks seit dem Jahre 1847, Sechster Bank: Der Kulturkampf 1871-1873. Berlin \& Stuttgart: Verlag von W. Spemann.

Borutta, M. (2003). "Enemies at the gate: The Moabit Klostersturm and the Kulturkampf: Germany. In C. M. Clark \& W. Kaiser (Eds.), Culture wars: Secular-Catholic conflict in nineteenth-century Europe (pp. 227-254). Cambridge, UK: Cambridge University Press.

Cetinsaya, G. (1999). Rethinking nationalism and Islam: Some preliminary notes on the roots of "Turkish-Islamic Synthesis" in modern Turkish political thought. The Muslim World, 89(3-4), 350-376. https://doi.org/10.1111/j.1478-1913.1999.tb02753.x.

Davison, R. H. (1982). The millets as agents of change in the nineteenth-century Ottoman Empire. In B. Braude \& B. Lewis (Eds.), Christian and Jews in the Ottoman Empire Vol. 1 The Central Lands (pp. 319-337). Princeton, NJ: Princeton University.

Dolezal, M., Helbling, M., \& Hutter, H. (2010). Debating Islam in Austria, Germany and Switzerland: Ethnic citizenship, church-state relations, and right-wing populism. West European Politics, 33(2), 171-190.

Dressler, M. (2002). Die alevitische Religion: Traditionslinien und Neubestimmungen. Vol. 53: Deutsche Mogenländische Gesellschaft.

Dressler, M. (2008). Religio-secular metamorphoses: The re-making of Turkish Alevism. Journal of the American Academy of Religion, 76(2), 280-311. https://doi.org/10.1093/jaarel/lfn033.

Dressler, M. (2013). Writing religion: The making of Turkish Alevi Islam. Oxford: Oxford University Press.

Epstein, D., \& O’halloran, S. (1994). Administrative procedures, information and agency discretion. American Journal of Political Science, 38(3), 697-722.

European Court of Human Rights (ECtHR). (2004). Leyla Şahin vs. Turkey. Strasbourg: Fourth Section.

European Court of Human Rights (ECtHR). (2007). Hasan and Eylem Zengin vs. Turkey. Strasbourg: Former Second Section.

Evans, E. L. (1984). Catholic political movements in Germany, Switzerland, and the Netherlands: Notes for a comparative approach. Central European History, 17(2/3), 91-119.

Evans, R. J. (2007). Nazism, christianity and political religion: A debate. Journal of Contemporary History, 42(1), 5-7.

Feldman, S., \& Zaller, J. (1992). The political culture of ambivalence: Ideological responses to the welfare state. American Journal of Political Science, 36(1), 268-307.

Gailmard, S. (2009). Discretion rather than rules: Choice of instruments to control bureaucratic policy making. Political Analysis, 17, 25-44.

Gailmard, S., \& Patty, J. W. (2007). Slackers and zealots: Civil service, policy discretion and bureaucratic expertise. American Journal of Political Science, 51(4), 873-889.

Geissbuehler, S. (2007). Are Catholics still different? Catholicism, political attitudes, and party attachments in Switzerland, 1970-95. West European Politics, 22(3), 223-240.

Gilles, R. P., \& Scotchmer, S. (1997). Decentralization in replicated club economies with multiple private goods. Journal of Economic Theory, 72, 363-387. 
Göle, N. (1997). The forbidden modern: Civilization and veiling, critical perspectives on women and gender. Ann Arbor: University of Michigan Press.

Gorski, P. S. (2003). The disciplinary revolution: Calvinism and the rise of the state in early modern Europe. Chicago: University of Chicago Press.

Gözaydın, İ. (2009). Diyanet: Türkiye Cumhuriyeti’nde Dinin Tanzimi. İstanbul: İletişim.

Greif, A. (1994). Cultural beliefs and the organization of society: A historical and theoretical reflection on collectivist and individualist societies. Journal of Political Economy, 102(5), 912-950.

Grigoriadis, I. N. (2008). Trials of Europeanization: Turkish political culture and the European Union. New York, London: Palgrave Macmillan.

Grigoriadis, I. N. (2009). Islam and democratization in Turkey: Secularism and trust in a divided society. Democratization, 16(6), 1194-1213.

Grigoriadis, T. (2016). Religious origins of democracy \& dictatorship. Journal of Policy Modeling, 38(5), 785-809.

Grigoriadis, I. N., \& Gurcel, T. (2014). Religious courses in Turkish public education: Explaining domestic change with Europeanization theory. Journal of Church and State, 56(2), 300-322.

Guiso, L., Sapienza, P., \& Zingales, L. (2008). Social capital as good culture. Journal of the European Economic Association, 6(2-3), 295-320.

Iannaccone, L. R., Haight, C. E., \& Rubin, J. (2011). Lessons from Delphi: Religious markets and spiritual capitals. Journal of Economic Behavior \& Organization, 77(3), 326-338.

Issawi, C. (1982). The transformation of the economic position of the millets in the nineteenth century. In B. Braude \& B. Lewis (Eds.), Christians and Jews in the Ottoman Empire: The functioning of a plural society (pp. 261-285). New York: Holmes and Meier Publishers.

Joppke, C. (2007). Beyond national models: Civic integration policies for immigrants in Western Europe. West European Politics, 30(1), 1-22. https://doi.org/10.1080/01402380601019613.

Karamustafa, A. T. (2007). Sufism: The formative period. Berkeley: University of California Press.

Kars, H. (1934). Kanzler und Kirche: Bismarcks grundsätzliche Einstellung zu den Kirchen während des Kulturkampfes. Gießen: Verlag von Alfred Töpelmann.

Katz, G. (2008). The Israeli Kulturkampf. Israeli Affairs, 14(2), 237-254.

Kaymakcan, R. (2006). Türkiye'de Din Eğitimi Politikaları Üzerine Düşünceler. EKEV Akademi Dergisi, 10(27), 21-36.

La Porta, R., Lopez-de-Silanes, F., Shleifer, A., \& Vishny, R. W. (1997). Trust in large organizations. American Economic Review, 87(2). In Papers and proceedings of the hundred and fourth annual meeting of the American Economic Association, pp. 333-338.

Lahrkamp, B. (1986). "Zur Auseinandersetzung zwischen katholischer Kirche und Nationalsozialismus im Münsterland. Eine Analyse kirchlicher Erlebnisberichte”, Westfälische Zeitschrift 136.

Lamberti, M. (1989). State, society and the elementary school in imperial Germany. New York/Oxford: Oxford University Press.

Lange, J. (1974). Die Stellung der überregionalen katholischen deutschen Tagespresse zum Kulturkampf in Preußen (1871-1878). Frankfurt/Main: Peter Lang.

Mardin, Ş. (1973). Center-periphery relations: A key to Turkish politics? Daedalus, 102(1), 169-190.

Merkel, R., \& Putzke, H. (2013). After Cologne: male circumcision and the law. Parental right, religious liberty or criminal assault? Journal of Medical Ethics, 39(7), 444-449.

Morsey, R. (2000). Bismarck und die deutschen Katholiken, Friedrichsruher Beiträge (Vol. 8). Friedrichsruh: Otto-von-Bismarck Stiftung.

Nipperdey, T. (1990). Deutsche Geschichte 1866-1918. Band 1. (München).

Nipperdey, T. (1998). Deutsche Geschichte: 1866-1918. Band 2. (München).

Ostrom, E. (2000). Collective action and the evolution of social norms. Journal of Economic Perspectives, 14(3), 137-158.

Özyürek, E. (2009). Convert alert: German Muslims and Turkish Christians as threats to security in the New Europe. Comparative Studies in Society and History, 51(1), 91-116.

Ross, R. J. (1998a). The failure of Bismarck's Kulturkampf: Catholicism and state power in imperial Germany, 1871-1887. Washington, DC: Catholic University of America Press.

Ross, R. J. (1998b). The failure of Bismarck's Kulturkampf: Catholicism and state power in imperial Germany, 1871-1887. Washington, DC: The Catholic University of America Press.

Saktanber, A., \& Çorbacioğlu, G. (2008). Veiling and headscarf-skepticism in Turkey. Social Politics, 15(4), 514-538.

Shankland, D. (2003). The Alevis in Turkey: The emergence of a secular Islamic tradition. Routledge Curzon: London, New York. 
Soysal, N. Y. (2007). Changing parameters of citizenship and claims-making: Organized Islam in European public spheres. Theory and Society, 26(4), 509-527.

Sperber, J. (1983). The shaping of political catholicism in the Ruhr Basin, 1848-1881. Central European History, 16(4), 347-367.

Spicer, K. P. (2004). Resisting the third Reich: The catholic clergy in Hitler's Berlin. De Kalb: Northern Illinois University Press.

Tambar, K. (2010). The aesthetics of public visibility: Alevi Semah and the paradoxes of pluralism in Turkey. Comparative Studies in Society and History, 52(03), 652-679.

Tank, P. (2005). Political Islam in Turkey: A state controlled secularity. Turkish Studies, 6(1), 3-21.

Unan, F., \& Hacaloğlu, Y. (1999). Cumhuriyetin 75. Yılında Türkiye'de Din Ĕ̆itimi ve Öğretimi. In Y. Hacaloğlu (Eds.). Ankara: Türk Yurdu.

Uwe, W. (2010). Das Deutsche Kaiserreich und seine Justi: Justizkritik-Politische Strafrechtsprechung-Justizpolitik. Berlin: Duncker \& Humblot.

Weber, M. (1920). Gesammelte Aufsätze zur Religionssoziologie, Bände I und III. Tübingen: Verlag von J. C. B. Mohr (Paul Siebeck).

Werner, Y. M., \& Harvard, J. (2013). European anti-catholicism in a comparative and transnational perspective-The role of a unifying other: An introduction. In Y. M. Werner \& J. Harvard (Eds.), European anti-catholicism in a comparative and transnational perspective (pp. 13-24). Rodopi: Amsterdam, New York.

Wiermann, H. (1885). Geschichte des Kulturkampfes: Ursprung, Verlauf und heutiger Stand. Leipzig: Gebhardt und Wilisch.

Zenkovsky, S. A. (1955). Kulturkampf in Pre-revolutionary Central Asia. American Slavic and East European Review, 14(1), 15-41. 